\title{
The Relationship Between Measures of Annual Livestock Disturbance in Western Riparian Areas and Stream Conditions Important to Trout, Salmon, and Char
}

Author(s): Lindsey M. Goss and http://orcid.org/0000-0003-1064-323XBrett B. Roper Source: Western North American Naturalist, 78(1):76-91.

Published By: Monte L. Bean Life Science Museum, Brigham Young University URL: http://www.bioone.org/doi/full/10.3398/064.078.0108

BioOne (www.bioone.org) is a nonprofit, online aggregation of core research in the biological, ecological, and environmental sciences. BioOne provides a sustainable online platform for over 170 journals and books published by nonprofit societies, associations, museums, institutions, and presses.

Your use of this PDF, the BioOne Web site, and all posted and associated content indicates your acceptance of BioOne's Terms of Use, available at www.bioone.org/page/terms of use.

Usage of BioOne content is strictly limited to personal, educational, and non-commercial use. Commercial inquiries or rights and permissions requests should be directed to the individual publisher as copyright holder. 


\title{
The relationship between measures of annual livestock disturbance in western riparian areas and stream conditions important to trout, salmon, and char
}

\author{
Lindsey M. Goss ${ }^{1,2}$ AND Brett B. Roper 1,3 ,* \\ ${ }^{1}$ Department of Watershed Sciences, Utah State University, 5210 Old Main Hill, Logan, UT 84332-5210 \\ 2 Present address: USDA Forest Service, Hiawatha National Forest, 8181 Highway 2, Rapid River, MI 49878 \\ ${ }^{3}$ USDA Forest Service, National Stream and Aquatic Ecology Center, 860 North 1200 East, Logan, UT 84321
}

\begin{abstract}
Managing livestock disturbance in riparian zones in a manner that provides economic returns to ranchers while protecting streams is an important aspect of rangeland management on public lands in the western United States. Attempts to balance economic and ecologic outcomes have been made more difficult due to the presence of several salmonid species that are protected under the Endangered Species Act. One approach to proper management of livestock use near streams has been to define the allowable limits of disturbance using 2 metrics, streambank alteration and stubble height. We evaluated 153 stream reaches within the Interior Columbia Basin to determine if these 2 surrogates of livestock disturbance measured after the vegetative growing season were associated with stream conditions important to salmonids evaluated the following summer. We found that each stream habitat attribute that was evaluated (width-todepth ratio, streambank angle, percent undercut banks, streambank stability, residual pool depth, percent pools, percent pool-tail fine sediments $<2 \mathrm{~mm}$, and wood frequency) trended toward lower-quality salmonid habitat as streambank alteration increased or as stubble height decreased. While the strength of these associations were variable, the slopes of the relationships suggest that managing the amount of streambank alteration or stubble height could influence stream conditions within the Interior Columbia Basin. Because improved stream conditions for salmonids corresponded to decreased livestock disturbance, the amount of disturbance allowed in a stream reach will need to reflect management expectations and the environmental setting within the allotment. As a starting point, we suggest the continued application of existing livestock disturbance standards in stream reaches with good habitat conditions, and the specification of more conservative disturbance standards in stream reaches that have degraded habitat conditions.
\end{abstract}

RESUMEN.-Un aspecto importante para el tratamiento de los pastizales, de las tierras públicas del oeste de los Estados Unidos es el control adecuado de las perturbaciones ganaderas en las zonas ribereñas, que proporcione ganancias económicas a los ganaderos mientras protege los arroyos. Los intentos por equilibrar los resultados económicos y ecológicos se han complicado debido a la presencia de varias especies de salmónidos, protegidos por la Ley de Especies en Peligro de Extinción. Un modelo de control adecuado del uso de ganado cerca de los arroyos consistió en definir los límites permisibles de perturbación, utilizando dos parámetros, las perturbaciones en las orillas de los arroyos o riberas y la altura de los rastrojos. Evaluamos 153 extensiones de arroyos, dentro de la Cuenca Interior de Columbia, para determinar si estas dos perturbaciones ganaderas evaluadas después de la temporada de crecimiento vegetativo, se relacionaron con las condiciones de los arroyos, que fueron importantes para los salmónidos evaluados en el siguiente verano. Encontramos que cada atributo evaluado del hábitat del arroyo: relación ancho-profundidad, ángulo de la ribera, porcentaje de bancos socavados, estabilidad de la ribera, profundidad residual de los estanques, porcentaje de estanques, sedimentos finos en el fondo $<2 \mathrm{~mm}$ y frecuencia de madera, a medida que aumentaba la alteración en las orillas de los arroyos o a medida que la altura de los rastrojos disminuía, tendían a ser hábitats de menor calidad para los salmónidos. Aunque, la fuerza de las relaciones fue variable, la pendiente sugiere que el control de la cantidad de perturbación en las orillas de los arroyos o de la altura del rastrojo podrían influir en las condiciones de los arroyos de la Cuenca Interior de Columbia. Debido a que, la mejoría en las condiciones de los arroyos para los salmónidos se correlaciona con la disminución de las perturbaciones causadas por el ganado, la cantidad de perturbación permitida en un arroyo debe reflejar las expectativas de la administración y del entorno ambiental dentro del área. En caso de que, un arroyo presente buenas condiciones de hábitat, sugerimos la aplicación continua de las normas existentes sobre las perturbaciones causadas por la ganadería, especificando el uso de normas de perturbación más conservadoras en los arroyos con condiciones de hábitat más degradadas.

*Corresponding author: broper@fs.fed.us

orcid.org/0000-0003-1064-323X 
Federal land managers have a legal mandate to manage public land for multiple uses. One component of this mandate is to promote healthy rangeland conditions while providing foraging opportunities for livestock. Attempts to balance these goals have been complicated by the Endangered Species Act (ESA) listing of several trout, salmon, and char species (Oncorhynchus spp., Salvelinus confluentus) within the Interior Columbia River Basin. The juxtaposition of livestock in riparian areas near streams that harbor ESA-listed fish requires land management agencies to formulate grazing strategies that do not jeopardize these populations or adversely modify these fishes' critical habitat. If livestock disturbance is not managed for the protection of streams and fish as described within agency planning documents, then the ESA and other laws provide the nexus for litigation by organizations interested in holding federal agencies and grazing permittees accountable (e.g., Oregon Natural Desert Association v. Lohn, 522 F. Supp. 2d 1295 [D. Or. 2007]).

To conduct livestock grazing in a manner that maintains or improves stream conditions important to salmonids, federal land managers and regulatory agencies use indicators of livestock disturbance measured annually as proxies for short-term effects to riparian areas. The most commonly measured indicators of nearstream grazing disturbance used by the Forest Service and Bureau of Land Management (BLM) are streambank alteration and stubble height. Streambank alteration is an estimate of how much of the streambank has been disturbed by ungulate hooves (Bengeyfield 2006, Burton et al. 2011), while stubble height is a measure of the herbaceous material that remains near the stream following grazing (Clary and Leininger 2000). Use of these annual indicators in grazing strategies to limit livestock disturbance in riparian areas can be supported if there is a relationship between these short-term disturbance metrics and the long-term stream conditions important to salmon, trout, and char. Such a relationship would be valuable to public land managers, especially if it indicated that proper "withinseason" livestock management not only protects stream conditions from the direct effects of grazing, but also limits the indirect negative effects to the stream channel due to the increased erosion rates associated with high stream flow events that occur between grazing seasons (Trimble and Mendel 1995, Swanson et al. 2015).

Numerous studies have demonstrated that livestock disturbance as measured by these proxies is related to stream habitat conditions at the reach scale within the same year (e.g., Clary and Webster 1990, Clary et al. 1996). However, these studies are dated, and they have not evaluated these relationships across a range of environmental settings, nor shown that the effects of livestock grazing disturbance are still discernable in the following year (Buckhouse et al. 1981). The failure to establish a more complete understanding of these associations has led to a reticence by ranchers, land management agencies, and regulatory agencies to accept specific numeric values as standards or objectives for these livestock disturbance proxies. The objective of this study is to describe the shape and strength of the relationship between streambank alteration and stubble height measured following the grazing season with stream channel characteristics important to salmonids measured the following year. In providing this understanding, we hope to strengthen the scientific foundation for using these annual indicators of livestock disturbance to improve stream conditions that support salmonids.

\section{Methods}

\section{Study Area and Sample Design}

From 2010 to 2012 we assessed livestock disturbance (primarily cattle, Bos taurus) near streams on federal lands within the Interior Columbia River Basin at locations being monitored by the PacFish/InFish Biological Opinion Effectiveness Monitoring Program (Kershner et al. 2004a). The stream reaches evaluated in this study were initially determined using a spatially balanced sample of watersheds from across the Interior Columbia River Basin, ensuring that a broad range of grazed stream reaches were evaluated. Within each watershed with livestock grazing, the local Forest Service or BLM administrative unit identified a designated monitoring area for evaluation within a randomly selected allotment. A designated monitoring area is a section of stream and riparian area chosen for evaluation because it is representative of livestock grazing impacts on streambanks and 


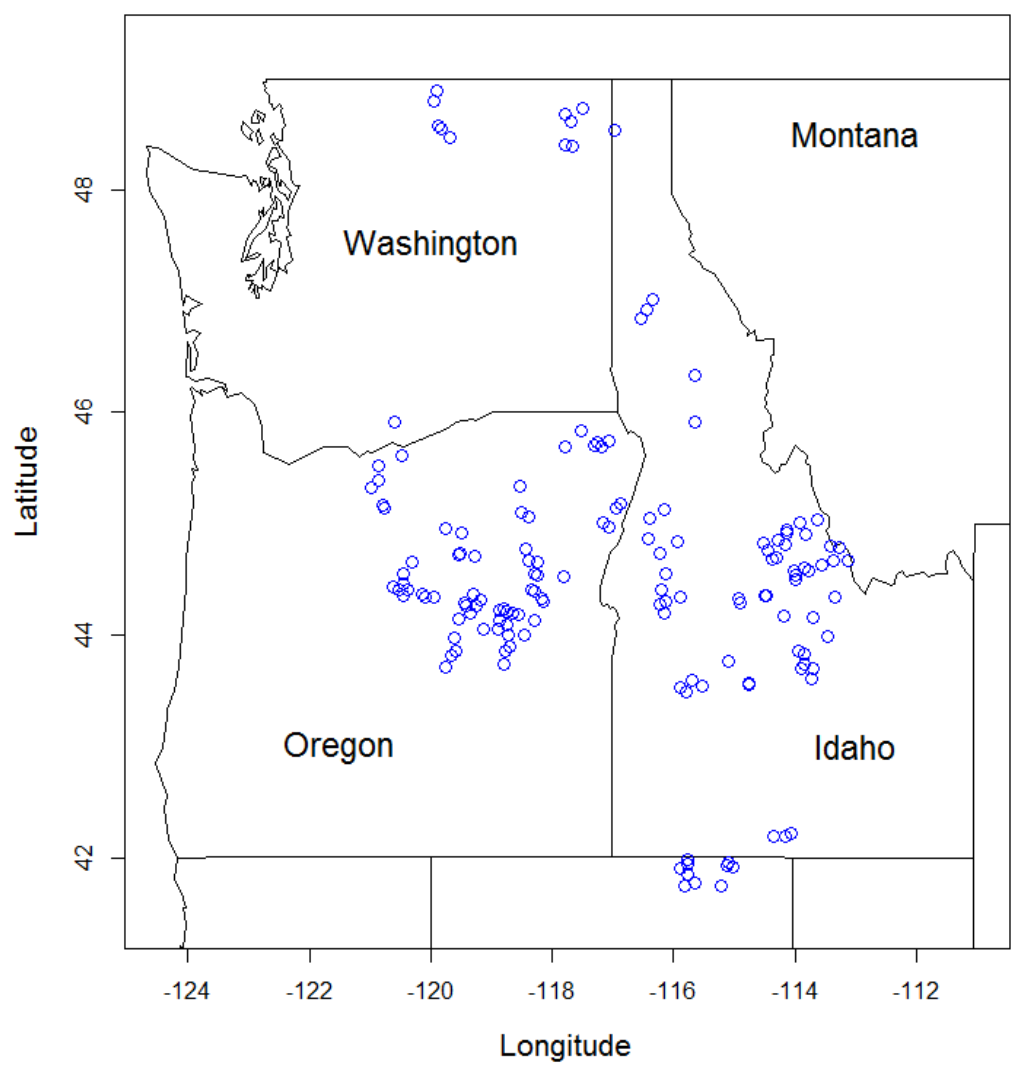

Fig. 1. Locations of the 153 sites evaluated in this study.

TABLE 1. Mean, median, and quartiles of selected climatic and landscape attributes associated with the evaluated stream reaches and the catchments above them.

\begin{tabular}{lcccc}
\hline Attribute & Mean & Median & 1st quartile & 3rd quartile \\
\hline Bankfull width $(\mathrm{m})^{\mathrm{a}}$ & 4.2 & 3.4 & 2.4 & 5.2 \\
Gradient $(\%)^{\mathrm{a}}$ & 2.6 & 2.1 & 1.2 & 3.4 \\
Area $\left(\mathrm{km}^{2}\right)^{\mathrm{b}}$ & 29.1 & 18.6 & 7.2 & 34.9 \\
Precipitation $(\mathrm{m})^{\mathrm{b}}$ & 0.66 & 0.63 & 47.5 & 0.76 \\
${\text { Forested }(\%)^{\mathrm{b}}}_{\text {Elevation }(\mathrm{m})^{\mathrm{a}}}$ & 65.3 & 76.5 & 1172 & 87.7 \\
Road density $\left(\mathrm{km} / \mathrm{km}^{2}\right)^{\mathrm{b}}$ & 1479 & 1447 & 0.57 & 1865 \\
Streambank alteration & 1.54 & 1.41 & 4.9 & 2.31 \\
Stubble height $(\mathrm{cm})^{\mathrm{a}}$ & 21.1 & 15.0 & 8.6 & 25.9 \\
\hline
\end{tabular}

aQuantified at the stream-reach scale

bQuantified at the catchment scale

riparian vegetation within that allotment (Winward 2000). Because cattle generally congregate in gently sloping landscapes, most designated monitoring areas were near lowgradient $(<4 \%)$ stream reaches. In these allotments livestock grazing could have occurred from late spring to early fall with specific grazing strategies and intensities determined in the Allotment Management Plan.
We evaluated 153 stream reaches on public lands where livestock grazing was permitted as part of a larger study attempting to describe grazing disturbance of riparian areas within the Interior Columbia River Basin (Goss 2013). All stream reaches used in this analysis had annual indicators of livestock disturbance evaluated at the end of the growing season (mid-September through October), with stream 
habitat conditions evaluated in the same stream reach the following summer. Although grazing was permitted along all the evaluated stream reaches, some allotments were rested (i.e., no livestock were present) in the year that we assessed livestock disturbance. Approximately $85 \%$ of the stream reaches were perennial, many were fish bearing, and they reflected the broad spectrum of riparian, stream, and watershed conditions grazed by livestock (Table 1, Fig. 1). For these stream reaches we evaluated the hypothesis that grazing practices, as measured with these indicators at the end of the grazing and growing season, were associated with stream habitat conditions the following year (Bryant et al. 2006, Swanson et al. 2015).

Sampling methods for livestock disturbance generally followed the Multiple Indicator Monitoring (MIM) protocol (Burton et al. 2011). Evaluated stream reaches were $110 \mathrm{~m}$ long and sampling occurred along the greenline, which is the first perennial vegetation that forms a lineal grouping on or near the water's edge, usually at or slightly below the bankfull discharge height (Winward 2000, Heitke et al. 2011). When no vegetation occurred on the streambank within $0.5 \mathrm{~m}$ of the bankfull width's elevation, sampling was moved to the first flat depositional feature at or above the bankfull level or at bankfull in stream reaches where no flat feature was present. This is a departure from MIM protocol (Burton et al. 2011), which permits measurements up to $6 \mathrm{~m}$ from the water's edge in riparian areas if there are extensive areas with bare ground. We decided against this approach because we thought that moving survey plots away from the streambanks would underestimate the effect of livestock disturbance on sediment runoff into the stream (Magilligan and McDowell 1997). Taking measurements near the stream channel increased the likelihood that the livestock disturbances we evaluated were directly tied to stream channel conditions important to fish (Armour et al. 1991, Bryant et al. 2006).

\section{Annual Indicators of Livestock Disturbance}

The 2 indicators of livestock disturbance we evaluated were streambank alteration and stubble height. Rapid estimates of streambank alteration and stubble height were

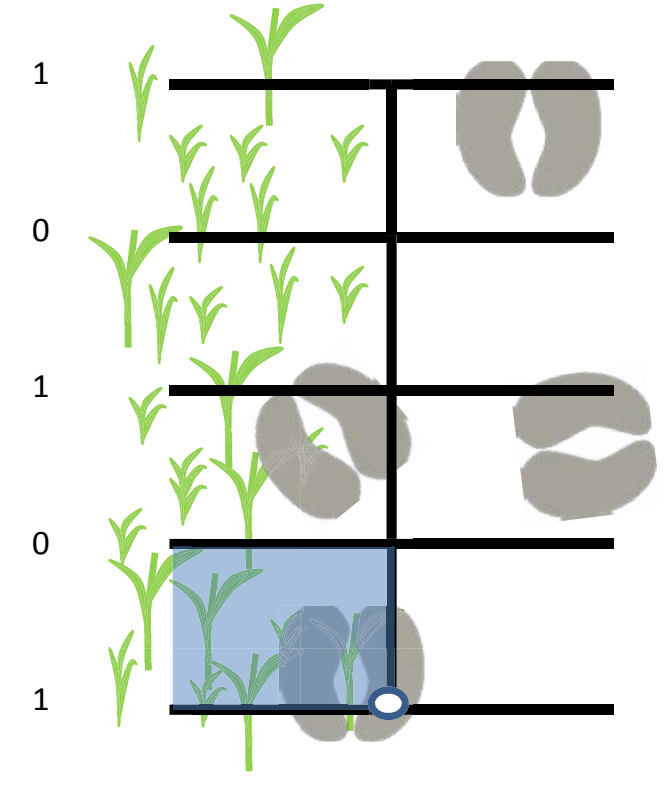

$3 / 5=60 \%$ bank alteration

Fig. 2. Plot placement and evaluation of metrics within a stream reach. The grass-like figures on the left half of the frame represent the vegetated portion of the greenline. The right side of the frame is toward the stream. The horizontal lines represent the portions of the frame used to assess streambank alteration. If a hoof touches any portion of these lines, the line is considered completely altered, as represented by the numeral 1 at the left of the plot. Measurements of streambank alteration displayed next to and underneath the plot show how alteration at each plot is calculated; as 3 of the 5 lines intercept at least one hoof print, this plot would have a $60 \%$ streambank alteration. Mean stubble height is measured in the first greenline cell (shaded) nearest the observer (dot at the bottom middle of the plot). These plot measurements occur approximately 80 times on each stream reach, and values used in this analysis are the mean values for the disturbance metrics.

obtained using a quadrat consisting of 2 adjoining $20 \times 50$-cm Daubenmire (1959) plots with the $50-\mathrm{cm}$ joining bar placed along the greenline (Fig. 2; Burton et al. 2011). Observers walked upstream on the left bank and downstream on the right bank of the 110 $\mathrm{m}$ reach, placing the quadrat on the greenline directly in front of their toe every 3 paces. This resulted in approximately 40 quadrat placements on each bank and approximately 80 plot measurements per reach. Streambank alteration and stubble height were recorded simultaneously with each quadrat placement so measurements of both indicators were taken at the same locations. 
TABLE 2. Definitions of the types of disturbances used to define streambank alteration by ungulates as evaluated in this study. A streambank was considered altered when any of these 3 ground disturbances could be determined to have occurred in the sampling year.

\begin{tabular}{ll}
\hline Type of ungulate alteration & Definition \\
\hline Shearing & Removal of a portion of the streambank by hooves, leaving a smooth vertical surface \\
& and an indentation of a hoof print at the bottom or along the sides. \\
Trampling & 13 mm deep or soil displacement at least $13 \mathrm{~mm}$ upwards. \\
& Trails/paths and other severe trampling are counted as alteration if there are signs of \\
Trailing & current year use. Because of compacted soils, trailing counts as disturbance even if \\
& hoof prints do not result in a 13-mm depression. \\
\hline
\end{tabular}

We determined streambank alteration using the approach described by Burton et al. 2011 . This streambank alteration protocol uses a 5-line intercept method to measure ungulate disturbance. Streambank alteration documents bank shearing, trampling, or trailing by recording disturbances left by hooves of wild and domesticated ungulates (Table 2; Heitke et al. 2008, Burton et al. 2011). The disturbance had to be visually distinctive and the result of current-season use. Streambank alteration within the plot was recorded as the total number of lines that intercepted depressions or hoof prints left by ungulates, regardless of the extent of the line that intercepted the print. Each line that overlapped a hoof disturbance represented $20 \%$ alteration for the 40 $\times 50-\mathrm{cm}$ quadrat area. A maximum of $100 \%$ alteration could be obtained if all 5 lines intercepted at least one disturbance caused by a hoof (Fig. 2). This approach to estimating streambank alteration overestimates the area disturbed by ungulate hooves but is repeatable among observers (Heitke et al. 2008, Goss 2013).

Methods for measuring stubble height were adapted from Burton et al. 2011 and the Utilization Studies and Residual Measurements Technical Reference (USDI-BLM 1999). Within the $40 \times 50$-cm sampling frame, stubble height was measured on the vegetated half of the quadrat frame in the first subplot $(12.5 \times 20 \mathrm{~cm}$; Fig. 2) nearest to the frame handle that had $\geq 25 \%$ herbaceous cover. Average height of all graminoids and forbs within the subplot were measured in one clump. We measured all herbaceous cover in order to replicate previous studies (Clary 1999, Clary and Kinney 2002). A zero was entered when stubble heights were $<1 \mathrm{~cm}$ or when vegetation was absent from all subplots if the lack of vegetation was due to grazing or trampling (e.g., cattle trails). For plots with stubble height $\geq 1 \mathrm{~m}, 100 \mathrm{~cm}$ was the maximum value we recorded. While Goss (2013) found the measurement of this attribute less repeatable than streambank alteration, the signal-to-noise ratio still exceeded 2 and the coefficient of variation was approximately $30 \%$, making it acceptable for use in monitoring (Roper et al. 2010).

Streambank alteration and stubble height values used in this analysis included the average of all the measurements in the stream reach that were subject to disturbance from livestock. Areas impervious to disturbance (i.e., embedded rock and downed trees) were excluded from the analysis. These impervious areas rarely represented much of the sampled area, generally $<5 \%$, because designated monitoring areas were defined as riparian areas where vegetation was an important agent in controlling stream channel form (Burton et al. 2011).

Over the 3-year study, measurements of livestock disturbance were taken by numerous individuals. Because training reduces observer differences (Heitke et al. 2008), all observers received 1 day of standardized field training each year and a written protocol of the methods to refer to while collecting data. Field training included direction on how to set up a reach, how to identify greenline, where to place the quadrat, how to identify ungulate streambank alteration, and how to evaluate the 2 proxies of livestock disturbance. Because the larger study was interested in estimating observer variation (Goss 2013), 2 observers simultaneously and independently estimated livestock disturbance at 102 of the 153 sites. We averaged the results of the 2 observers for the stream reach values used in this analysis. As part of this larger study (Goss 2013), some stream reaches were evaluated multiple times 
TABLE 3. The stream attributes evaluated in this study related to improved salmonid habitat. The direction of change of the attribute listed as positive is related to increased salmonid growth, survival, and/or abundance. The sources for these expected relationships are listed under citations.

\begin{tabular}{lcl}
\hline Stream attribute & Positive change & Citations \\
\hline Width-to-depth ratio & Decrease & Clarkson and Wilson 1995 \\
Bank angle $\left(^{\circ}\right)$ & Decrease & Knapp and Matthews 1996 \\
$\%$ Undercut banks & Increase & Kozel et al. 1989 \\
Bank stability $(\%)$ & Increase & Clarkson and Wilson 1995 \\
Residual pool depth $(\mathrm{m})$ & Increase & McIntosh et al. 2000 \\
$\%$ Pools & Increase & Magilligan and McDowell 1997 \\
$\%$ Pool-tail fine sediment $<2 \mathrm{~mm}$ & Decrease & Chapman 1988, Al-Chokhachy et al. 2010a \\
Wood frequency $($ no. $/ \mathrm{km})$ & Increase & Saunders and Fausch 2007, Nusslé et al. 2017 \\
\hline
\end{tabular}

at the end of the season to evaluate temporal variation; we included only the latest occurring survey in the year for this analysis.

\section{Stream Habitat Conditions}

Stream habitat conditions were determined the summer following the evaluation of streambank alteration and stubble height. The stream attributes evaluated included reach average bankfull width-to-depth ratio, reach average streambank angle, percent of the stream reach with undercut banks, reach average bank stability, average residual pool depth, percent of the reach that was pool habitat, percent of the pool-tails covered by fine sediments $<2 \mathrm{~mm}$, and wood frequency (pieces had to be $>0.1 \mathrm{~m}$ in diameter by $3 \mathrm{~m}$ long to be counted as wood). Each of these 8 indicators of stream condition have been shown to be affected by livestock grazing (Kauffman et al. 1983, Platts and Nelson 1985, Myers and Swanson 1995, Knapp and Matthews 1996, Clary 1999, Clary and Kinney 2002, Ranganath et al. 2009) and to be important to salmonids (Rosenfeld et al. 2000, Al-Chokhachy et al. $2010 \mathrm{~b})$. In general, salmonid densities are expected to increase as undercut banks, bank stability, pool depth, percent pools, and wood frequency increase and expected to decrease as width-to-depth ratio, bank angle, and fine sediments in pool-tails increase (Table 3). Field methods for these stream habitat attributes are described in Heitke et al. (2011), while a description of protocol repeatability can be found in Roper et al. (2010).

\section{Data Analysis}

Our hypothesis was that the extent of nearstream livestock disturbance, as estimated by the measurement of streambank alteration or stubble height, was related to stream habitat conditions the following year. If this relationship is substantiated, then the high stream flows that occur between grazing seasons may either exacerbate or mediate the effects of livestock disturbance on stream conditions from one year to the next (Bryant et al. 2006, Swanson et al. 2015). If no such relationship is found, then the effect of livestock disturbance may be undetectable given background stream channel erosion rates (Buckhouse et al. 1981). For example, if livestock grazing resulted in excessive streambank alteration or limited vegetation height at the end of the grazing season, then high-flow events between the grazing seasons would increase erosion along the disturbed banks (Trimble and Mendel 1995) and further degrade stream habitat conditions (e.g., reduced bank angles and fewer undercut streambanks) the following year. In contrast, if livestock grazing near the stream minimized disturbance and protected aboveground vegetation, channel conditions would either be maintained or trend toward conditions that fostered trout and salmon populations (Nusslé et al. 2017).

To test this hypothesis we constructed linear regression models that related the outcomes of our evaluations of streambank alteration and stubble height to stream habitat conditions (width-to-depth ratio, bank angle, percent undercut banks, bank stability, residual pool depth, percent pools, pool-tail fine sediments $<2 \mathrm{~mm}$, and wood frequency) measured the following year. We incorporated environmental covariates into our analysis to account for inherent variability among the stream reaches. For simplicity, we limited the potential covariates to bankfull width, reach gradient, and average annual precipitation (PRISM 2012; average from 1981 to 2010). Each of these attributes has previously been shown to have a 
strong relationship to the conditions of stream habitat attributes (Kershner et al. 2004b) and are not strongly correlated $(r<|0.22|)$ to each other.

We determined the best model for each stream habitat attribute using backward stepwise regression with the Akaike information criterion (AIC) to determine which covariates and livestock disturbance metrics were included in the best model. For each disturbance metric we evaluated the possibility of linear and second-order polynomial components within the model. We included the possibility of a second-order polynomial because inclusion of this term suggests curvature, indicating that the effects of grazing on stream conditions were not constant across livestock disturbance intensities. If the full model was selected as the best model, it would be represented as

$$
\begin{aligned}
\text { Stream Attribute }= & \text { Bankfull }+ \text { Gradient } \\
& + \text { Precipitation }+ \text { Disturbance } \\
& +(\text { Disturbance })^{2},
\end{aligned}
$$

where stream attribute is each of the 8 stream habitat attributes independently; bankfull, gradient, and precipitation represent the possible covariates; and disturbance is either streambank alteration or stubble height. We didn't evaluate models that included both disturbance metrics at the same time because these metrics were correlated $(r=-0.38$; Goss 2013), and doing so may have led to results that were difficult to interpret (Whittingham et al. 2006).

We present the best overall model and the best covariate model to better understand the importance of the livestock disturbance metric in the model. In comparing these 2 models for each stream habitat attribute, we present the significance of the livestock disturbance metrics, the adjusted $R^{2}$ of both models, and the change in the AIC value.

We then assessed the best models with commonality analysis to ensure that the relationships between livestock disturbance metrics and stream habitat conditions were not obfuscated by concerns related to the use of multiple regression, such as collinearity or order of variable entry into the model (Whittingham et al. 2006). Commonality analysis allowed us to decompose the variance of the models for each of 8 stream habitat attributes and determine the unique and common variance associated with the livestock disturbance indicators and the covariates (Nimon et al. 2013).

To better understand the relative magnitude of how livestock disturbance might affect stream conditions, we presented the predicted effects of livestock disturbance in the context of changes in environmental conditions (Meredith et al. 2014). This was achieved by comparing the predicted effects of livestock disturbance on the stream habitat characteristics at 2 values commonly used as management standards for streambank alteration $(10 \%$ and $25 \%)$ and stubble height $(10 \mathrm{~cm}$ and $15 \mathrm{~cm})$ to the expected difference in habitat conditions going from a dry $(0.5 \mathrm{~m}$ of precipitation per year) to a wet $(0.75 \mathrm{~m}$ per year) watershed within the study area. We used precipitation as the environmental attribute because stream conditions in this region are responsive to it (Irvine et al. 2015). The 2 specific precipitation values $0.5 \mathrm{~m}$ and $0.75 \mathrm{~m}$ were selected because they were approximately the 1st and 3rd quartile values for this attribute within our sample (Table 1). If differences in expected stream conditions between competing livestock disturbance standards are small relative to differences in environmental conditions, the choice of a livestock disturbance standard will have little effect on stream conditions because small differences will be obscured by the environmental differences within the study area.

All analyses and graphics were produced in base R (R Core Team 2013) and the packages car (Fox and Weisberg 2011), MASS (Venables and Ripley 2002), yhat (Nimon et al. 2013), and maps (Becker and Wilks 2013).

\section{Results}

The best models for the evaluated stream habitat attributes explained between $16 \%$ and $66 \%$ of the variation and always included a livestock disturbance metric (Table 4). Streambank alteration was the disturbance metric incorporated into the models of width-todepth ratios and pool-tail fines (\% fine sediment $<2 \mathrm{~mm}$ ), while stubble height improved models for bank angle, undercut banks, bank stability, residual pool depth, percent pools, and wood frequency (Fig. 3). All the stream habitat models that incorporated stubble height 


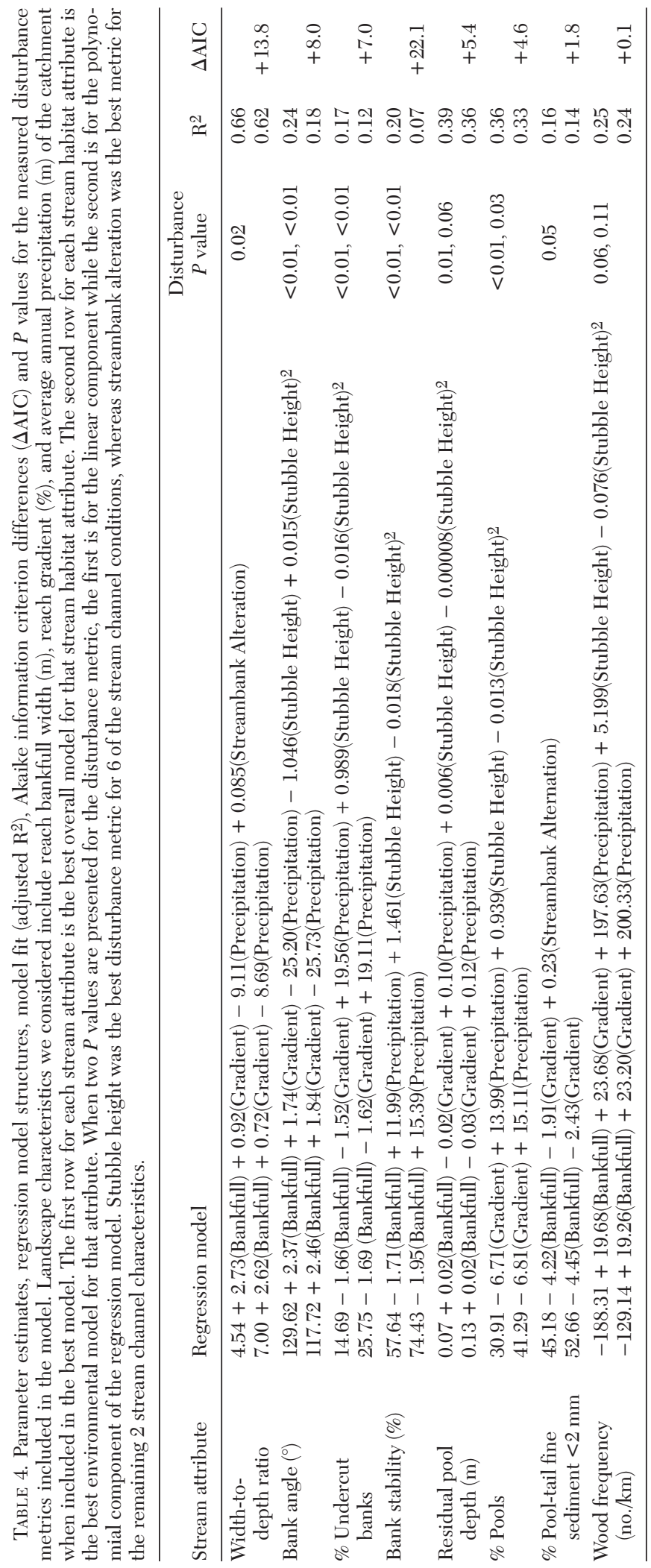



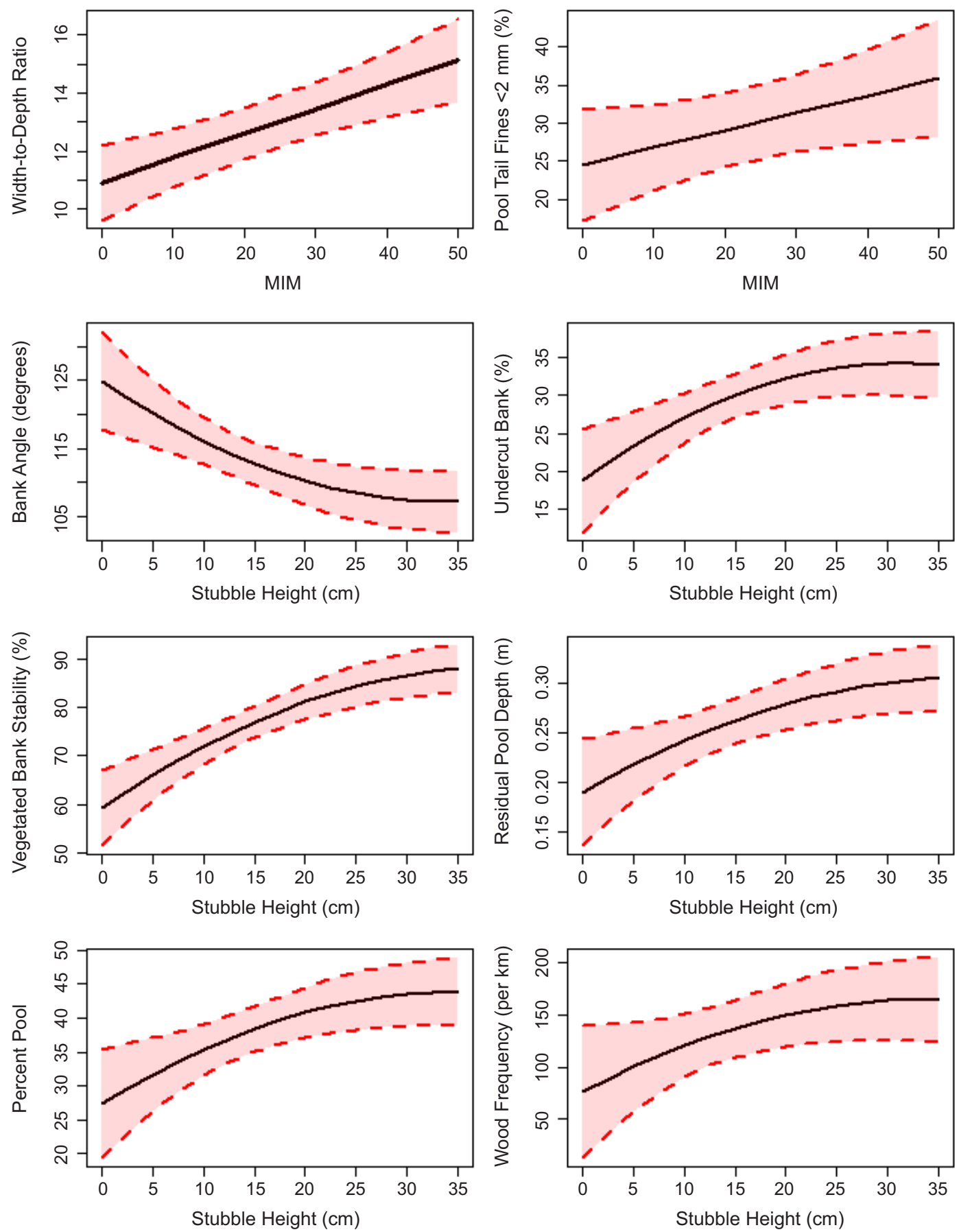

Fig. 3. The best relationship (with $90 \%$ confidence intervals) between streambank alteration and stubble height and the 8 stream habitat attributes. To account for the inclusion of covariates, our results are presented relative to a stream with a bankfull width of $4 \mathrm{~m}$, a gradient of $2 \%$, and precipitation of $0.7 \mathrm{~m}$ (when those environmental attributes are in the model for a specific stream habitat condition). The top 2 figures are stream habitat attributes related to streambank alteration while the rest are related to stubble height. 
included the polynomial term, suggesting a decreasing benefit to the stream habitat conditions as stubble heights increased. The relationship between stubble height and the stream attributes did not asymptote in the $10-15-\mathrm{cm}$ height range commonly used as standards (Clary and Webster 1990), and stream conditions favored by salmonids continued to improve as stubble height reached approximately $35 \mathrm{~cm}$.

All the best models for the 8 stream habitat attributes included terms where livestock disturbances, either greater streambank alteration or shorter stubble heights, were significantly $(P<0.1)$ related to what would be considered poorer stream habitat conditions for salmonids (Fig. 3, Tables 3, 4). Although the livestock disturbance indicator often explained only a small portion of the total variation, this was not always true. For example, stubble height explained nearly twice as much variability as the covariates model for bank stability. Furthermore, the slope of the disturbance metrics, after controlling for the covariates, suggested biologically meaningful changes at the large scale even if the outcomes were variable at a stream reach (Fig. 3).

The covariates played an important role in understanding the stream habitat characteristics (Kershner et al. 2004b). Bankfull width and gradient were related to the stream habitat conditions in a manner that suggested a positive relationship with increasing stream energy (Knighton 1998). As stream bankfull width increased so did the width-to-depth ratios, streambank angles, pool depths, and wood frequency. Also, as bankfull width increased there were fewer undercut banks, less stable streambanks, and less fine sediment in pool-tails. Higher-gradient stream reaches had greater width-to-depth ratios, more obtuse bank angles, fewer undercut streambanks, shallower pools, less pool habitat, fewer fine sediments, and more wood.

The relationship between stream attributes and precipitation suggested that increased precipitation altered vegetative growth in a manner that increased cohesiveness of streambanks and narrowed the stream channel (Anderson et al. 2004). Increased annual precipitation decreased width-to-depth ratios and bank angles while increasing the number of undercut banks, bank stability, residual pool depths, percent pools, and wood frequency.
The use of commonality analysis strengthened our interpretation of the relationships between indicators of livestock disturbance and stream habitat attributes. Commonality analysis indicated that stubble height was the most important variable in predicting percent undercut banks and bank stability and was second only to bankfull width in predicting bank angle and percent pools. In contrast, even though streambank alteration explained a significant amount of the variation in width-to-depth ratios, much of the variation was confounded with bankfull width and precipitation.

The strength of the associations between livestock disturbance and stream channel characteristics indicates that a biologically meaningful change in stream channel conditions could be achieved by reducing livestock disturbance. The difference in the predicted mean stream conditions between the lower and higher standard for both disturbance metrics was approximately $9 \%$ (range $\sim 3 \%$ to $20 \%$ ). The difference in going from a drier site to a wetter site at the same level of livestock disturbance was approximately $17 \%$ (range $\sim 4 \%$ to $61 \%$ ). These differences suggest that the average predicted change in stream habitat condition when going from a streambank alteration of $10 \%$ to $25 \%$ or a stubble height of $10 \mathrm{~cm}$ to $15 \mathrm{~cm}$ was about half the difference of increasing annual precipitation from $0.5 \mathrm{~m}$ per year to $0.75 \mathrm{~m}$ per year (Table 5 ).

\section{Discussion}

Measurements of streambank alteration or stubble height in the fall following the grazing season provided insight into stream habitat conditions important to salmonids measured the following year. We found such relationships surprising given the variability in the measurement of livestock disturbance (Heitke et al. 2008, Goss 2013) and stream habitat conditions (Roper et al. 2010), the variation in livestock use among years (Goss 2013), and the differences in site conditions across the 3 years of the study. Such factors should have clouded the strength of observed relationships (Al-Chokhachy and Roper 2010).

Increased livestock disturbance, as assessed with streambank alteration and stubble height, was related to stream channel changes through increases in width-to-depth ratios, bank angles, 
TABLE 5. Predicted conditions of stream attributes given a specified amount of livestock disturbances at 2 levels of precipitation. Comparisons were standardized to a stream with a $4-\mathrm{m}$ bankfull width and a gradient of $2 \%$. The top portion of the table are the attributes that were related to streambank alteration while the bottom are those related to stubble height.

\begin{tabular}{|c|c|c|c|c|}
\hline \multirow[b]{3}{*}{ Stream attribute } & \multicolumn{2}{|c|}{ Dry $(0.5 \mathrm{~m})$} & \multicolumn{2}{|c|}{ Wet $(0.75 \mathrm{~m})$} \\
\hline & \multicolumn{2}{|c|}{ Streambank alteration } & \multicolumn{2}{|c|}{ Streambank alteration } \\
\hline & $10 \%$ & $25 \%$ & $10 \%$ & $25 \%$ \\
\hline \multirow{4}{*}{$\begin{array}{l}\text { Width-to-depth ratio } \\
\% \text { Pool-tail fine sediment }<2 \mathrm{~mm}\end{array}$} & 13.6 & 14.8 & 11.3 & 12.6 \\
\hline & \multicolumn{4}{|c|}{ Precipitation not in best environmental model } \\
\hline & \multicolumn{2}{|c|}{ Stubble height } & \multicolumn{2}{|c|}{ Stubble height } \\
\hline & $10 \mathrm{~cm}$ & $15 \mathrm{~cm}$ & $10 \mathrm{~cm}$ & $15 \mathrm{~cm}$ \\
\hline Bank angle $\left(^{\circ}\right)$ & 121.1 & 117.8 & 114.8 & 111.5 \\
\hline$\%$ Undercut banks & 23.1 & 26.1 & 28.0 & 31.0 \\
\hline Bank stability & 69.6 & 74.6 & 72.6 & 76.4 \\
\hline Residual pool depth (m) & 0.22 & 0.24 & 0.25 & 0.27 \\
\hline$\%$ Pools & 32.6 & 35.6 & 36.0 & 39.1 \\
\hline Wood frequency (no./km) & 80.9 & 97.4 & 130.4 & 146.8 \\
\hline
\end{tabular}

and fine sediment in pool-tails and decreases in undercut banks, bank stability, pool habitat, pool depth, and wood frequency. The direction of these changes were what was expected given previous research of how livestock disturbance affects stream conditions important to salmon, trout, and char (Table 3). Our work supports previous localized studies that found increased livestock disturbance along streams is related to increases in width-todepth ratio (Stuber 1985, Platts 1991, Knapp and Matthews 1996, Matthews 1996, Clary 1999), streambank angle (Platts 1991, Myers and Swanson 1995, Knapp and Matthews 1996, Belsky et al. 1999, Clary and Kinney 2002), and fine sediment (Knapp and Matthews 1996, Clary 1999), and decreases in undercut banks (Kauffman et al. 1983, Myers and Swanson 1995, Knapp and Matthews 1996), streambank stability (Kauffman et al. 1983, Platts 1991, McIver and McInnis 2007), pool habitat (Myers and Swanson 1996, Magillian and McDowell 1997), pool depth (Myers and Swanson 1995), and woody material (Booth et al. 2012). Although the analyses we conducted show results independently for each stream attribute, it is important to recognize that increasing livestock disturbance negatively affects all of the stream channel characteristics we evaluated. The synergistic adverse effects of livestock disturbance on stream channel characteristics could therefore negatively affect salmonid densities and survival of all life stages occurring within a disturbed stream reach (Platts 1991).
The relationship we found between the stream channel profile and the measurement of streambank alteration across 153 sampled stream reaches reinforced the pattern Bengeyfield (2006) described in 2 streams, specifically that increased streambank alteration by livestock widens stream channels. The increases in the bankfull width-to-depth ratios were likely brought about through mechanical disturbance by hooves (Hofmann and Ries 1991, Trimble and Mendel 1995), which accelerated erosion through hydraulic action during the high streamflow events of the following winter (Kauffmann et al. 1983, Trimble 1994). Streambanks destabilized by hoof disturbance result in accelerated hydraulic erosion, which creates paths for overland flow thereby increasing sediment input into stream channels (Trimble 1994, Micheli and Kirchner 2002, Bengeyfield 2006). Increased sediment entering the stream during spring and fall could influence spawning success of salmon, trout, and char (Chapman 1988).

Five of the 6 stream habitat conditions related to stubble height-bank angle, undercut banks, bank stability, percent pools, and pool depth—suggested that livestock grazing is altering riparian plant communities in a manner that reduces the streambank's ability to resist high stream flows (Clary and Kinney 2002, Micheli and Kirchner 2002, Hough-Snee et al. 2013). When too much riparian vegetation is consumed during a summer grazing season it can reduce aboveground biomass production (Clary and Kinney 2002, Swanson 
et al. 2015). The loss of aboveground biomass can alter cattle foraging behavior (Ungar et al. 1991) and result in a shift to consumption of more woody material (Pelster et al. 2004).

Others have found that stubble height measured along the greenline is not only a good indicator of plant vigor but also the presence of livestock along streambanks (Skinner 1998, Bryant et al. 2006, Saunders and Fausch 2007). This suggests that some redundancy exists in the evaluation of streambank disturbance and stubble height (Goss 2013). While either of these indicators measured alone has value, management decisions will be better informed when both disturbance metrics are evaluated (Burton et al. 2011).

We suggest stubble height was incorporated into more models than streambank alteration because stubble height is directly affected by livestock grazing and is not as subject to changing environmental conditions along the streambanks as soil moisture is (Marlow et al. 1987, Micheli and Kirchner 2002). There were several stream reaches with short stubble heights but little streambank alteration. These stream reaches often showed evidence of compaction, making it difficult to detect current-year evidence of disturbance by hooves. In contrast, there were stream reaches with tall stubble heights and considerable streambank alteration. In these stream reaches, the greenline was often at the level of the water table or there had been recent rainfall; both situations can increase the likelihood that alteration by livestock hooves will be detected. The added variability in streambank alteration measurement due to antecedent soil moisture likely decreased the strength of the relationship between this livestock disturbance metric and stream habitat conditions (Goss 2013).

These livestock disturbance proxies explained $1 \%$ to $13 \%$ of the variability in stream habitat attributes and had effect sizes (slopes of the relationships) steep enough to suggest that meaningful changes in mean stream conditions would occur depending upon how much livestock disturbance was allowed in riparian areas. Commonality analysis reinforced this finding by suggesting livestock disturbance was as or more important than the environmental metrics for several of the stream attributes. The consistency of these results suggest that use of these 2 livestock disturbance indicators should remain an important aspect of monitoring livestock use in riparian areas on public lands.

Our understanding of the relationship between livestock disturbance metrics and stream habitat conditions at the large scale should be tempered when applied at the individual site. The high variability in our models suggests that the local vegetative community, soils, and channel conditions may mediate or accentuate the general relationships we found between livestock disturbance and stream conditions (Bryant et al. 2006). The large number of factors that shape current stream reach conditions makes it difficult to apply general relationships found between livestock disturbance and stream habitat conditions to a specific stream reach with a high level of certainty (Swanson et al. 2015). This difficulty indicates that while ranchers, land managers, and regulatory agencies must be aware of these general relationships, they should be willing to override model predictions when conditions at a site indicate it is possible to have more or less livestock disturbance and still maintain stream conditions important to salmonids.

The existence of biologically meaningful and statistically significant relationships supports the use of these metrics as tools to manage livestock disturbance in riparian areas (Clary and Leininger 2000, Heitke et al. 2008, Goss 2013). The question then is what should be the standard for streambank alteration or stubble height. Determining a livestock disturbance standard would be simpler if predicted stream habitat conditions were maximized in the range of values currently used as standards by the land management agencies. Instead, 2 of the 8 stream habitat models had linear relationships, indicating that increased streambank alteration decreased the stream conditions favored by salmonids (Fig. 3). The relationship between stubble height and the remaining 6 stream habitat conditions attributes did have curvature but suggested that stream conditions favored by salmon, trout, and char were still improving as stubble height exceeded values commonly used as livestock disturbance standards $(10-15 \mathrm{~cm}$; Clary and Webster 1990).

Basing disturbance standards on these regression models alone fails to recognize the role natural disturbance plays in the formation of stream channels (Reeves et al. 1995, Roper 
et al. 2007). In the absence of livestock, wild ungulates would likely utilize riparian areas at a magnitude high enough to alter the riparian vegetation and stream conditions (Ripple and Beschta 2007, Averett et al. 2017). Hydrologic disturbance such as floods and droughts alter stream channels in a manner that provides habitat patchiness important to fish (Lake 2000). This suggests it is unrealistic to expect all stream reaches to foster conditions ideal for salmonids all the time (Reeves et al. 1995). Instead, the question land management and regulatory agencies must address is which management standards will protect streams from overgrazing while allowing stream processes to reflect historic environmental and disturbance gradients (Al-Chokhachy et al. 2010a) and still be economically viable for the rancher to implement.

\section{Conclusion}

Managing riparian areas on public lands in the presence of domestic livestock is difficult because it requires managers to protect ecological processes while fostering economic returns to ranchers. Decisions that balance ecological and economic outcomes can only be achieved if the land manager and rancher have a similar and clear understanding of what riparian and stream conditions are desired following livestock grazing (Clary and Leininger 2000). Once desired conditions for the stream and riparian area have been agreed on, then a numeric standard for streambank alteration or stubble height can be set with the goal of achieving those conditions (Bryant et al. 2006). In streams and riparian areas occupied by ESA-listed species, the balance of risk should tilt toward ecological function rather than livestock production. Following the precautionary principle and based on our findings that increased livestock disturbance can degrade stream conditions important to salmonids, implementing more conservative standards such as a $15-\mathrm{cm}$ standard for stubble height seems prudent until there is sufficient sitespecific data to justify more liberal standards (Clary and Webster 1990). It is more difficult to suggest a conservative standard for streambank alteration as there are differences between the protocols used in the literature (Bengeyfield 2006) and this study (Burton et al. 2011). Translating Bengeyfield's (2006) line-intercept approach, where a streambank alteration of $17 \%$ improved stream conditions, to the pseudo-line approach used in this paper (Burton et al. 2011) suggests that a conservative starting point for this metric using the protocol in this paper may be 25\% (Heitke et al. 2008, Goss 2013). The lack of published studies, however, makes such a conclusion tenuous without additional study.

While this study focused on understanding the relationship between short-term indicators of grazing disturbance and long-term stream conditions, it supports other work suggesting a need to increase accountability in implementing rangeland standards (Veblen et al. 2014, Carter et al. 2017). We are aware of very few Forest Service or BLM units in our study area where livestock disturbance standards are $>25 \%$ for streambank alteration or $<10$ $\mathrm{cm}$ for stubble height, yet more than a quarter of the stream reaches we sampled did not meet these standards. So while understanding the relationship between livestock disturbance and stream conditions is necessary to protect salmon, trout, and char habitat, setting the proper standard will not have the intended effect of maintaining or improving stream conditions if standards are not implemented and enforced.

Our study conducted at the large scale (>100 stream reaches across 4 states) reinforced previous research conducted at the smaller scale (generally a few stream reaches in the same basin) that found that livestock disturbance in riparian areas can negatively affect conditions of many stream attributes. The general guidance provided by our data is that lower streambank alteration and higher stubble heights can be used as a proxy to improve stream habitat conditions important to salmonids. The high variance in our models suggests it will be important for managers to consider where allotment-level stream reach conditions fall within these general relationships in order to balance environmental concerns with economic returns. This would suggest that areas which already possess favorable stream conditions for salmonids can be managed in a manner that reflects existing grazing strategies, even if more liberal livestock disturbance standards were applied. In contrast, allotments with poor riparian and stream conditions will likely need less streambank alteration and taller stubble heights in order to improve 
stream conditions important to salmon, trout, and char.

\section{ACKNOWLEDGMENTS}

We thank the staff of the PacFish/InFish Biological Opinion (PIBO) Effectiveness Monitoring Program, in particular Eric Archer, Ryan Leary, Jeremiah Heitke, Tim Romano, Jeff Ojala, Andrew Van Wagenen, and Rebecca Scully for their contributions to this project. An earlier version of this paper was substantially improved by comments from Chris Luecke, Eric Archer, Cynthia Tait, Scott Spaulding, Christy Meredith, Steve Smith, Bryce Bohn, and Nat Gillespie. These reviewers' comments did not always point the same direction, but discussions with these individuals greatly improved the paper. The data were collected by the PIBO Effectiveness Monitoring Program, but this manuscript represents the interpretation of these data by the authors. Financial support was provided by the U.S. Forest Service, Utah State University, the Bureau of Land Management, the Environmental Protection Agency, the U.S. Fish and Wildlife Service, and NOAA Fisheries.

\section{Literature Cited}

Al-Сhoкhachy, R., and B.B. Roper. 2010. Different approaches to habitat surveys can impact fisheries management and conservation decisions. Fisheries 35:476-488.

Al-Chokhachy, R., B.B. Roper, and E.K. Archer. 2010a. Evaluating the status and trends of physical stream habitat in headwater streams within the interior Columbia River and upper Missouri River basins using an index approach. Transactions of the American Fisheries Society 139:1041-1059.

Al-Chokhachy, R., B.B. Roper, T. Bowerman, and P. BuDY. 2010b. A review of bull trout habitat associations and exploratory analyses of patterns across the Interior Columbia River Basin. North American Journal of Fisheries Management 30:464-480.

Anderson, R.J., B.P. Bledsoe, And W.C. Hession. 2004. Width of streams and rivers in response to vegetation, bank material, and other factors. Journal of the American Water Resources Association 40: 1159-1172.

Armour, C.L., D.A. Duff, and W. Elmore. 1991. The effects of livestock grazing on riparian and stream ecosystems. Fisheries 16:7-11.

Averett, J.P., B.A. Endress, M.M. RowLAND, B.J. NAYLOR, AND M.J. WISDOM. 2017. Wild ungulate herbivory suppresses deciduous woody plant establishment following salmonid stream restoration. Forest Ecology and Management 391:135-144.
Becker, R.A., And A.R. Wilks. 2013. R Maps: Draw Geographical Maps. $\mathrm{R}$ package version 2.3-2. http:// CRAN.R-project.org/package $=$ maps

Belsky, A.J., A. Matzke, and S. Uselman. 1999. Survey of livestock influences on stream and riparian ecosystems in the western United States. Journal of Soil and Water Conservation 54:419-431.

Bengeyfield, P. 2006. Managing streams with cows in mind. Rangelands 28:3-6.

Booth, D.T., S.E. Cox, G. Simonds, and E.D. Sant. 2012. Willow cover as a stream-recovery indicator under a conservation grazing plan. Ecological Indicators 18:512-519.

Bryant, L., W. Burkhardt, T. Burton, W. Clary, R. Henderson, D. Nelson, W. Ririe, K. Sanders, and R. WILEY. 2006. Using stubble height to monitor riparian vegetation. Rangelands 28:23-28.

Buckhouse, J.C., J.M. Skovlin, and R.W. Knight. 1981. Streambank erosion and ungulate grazing relationships. Journal of Range Management 34:339-340.

Burton, T.A., S.J. SMith, AND E.R. Cowley. 2011. Riparian area management: multiple indicator monitoring (MIM) of stream channels and streamside vegetation. Technical Reference BLM/OC/ST-10/003+ 1737, U.S. Department of the Interior, Bureau of Land Management Denver, CO. 155 pp.

Carter, J., J.C. Catlin, N. Hurwitz, A.L. Jones, and J. RATNER. 2017. Upland water and deferred rotation effects on cattle use in riparian and upland areas. Rangelands 39:112-118.

Chapman, D.W. 1988. Critical review of variables used to define effects of fines in redds of large salmonids. Transactions of the American Fisheries Society 117: $1-21$.

Clarkson, R.W., and J.R. Wilson. 1995. Trout biomass and stream habitat relationship in the White Mountain Area, east-central Arizona. Transactions of the American Fisheries Society 124:599-612.

CLARY, W.P. 1999. Stream grazing and vegetation responses to late spring cattle grazing. Journal of Range Management 52:218-227.

Clary, W.P., and J.W. Kinney. 2002. Streambank and vegetation response to simulated cattle grazing. Wetlands 22:139-148.

Clary, W.P., and W.C. Leininger. 2000. Stubble height as a tool for management of riparian areas. Journal of Range Management 53:562-573.

Clary, W.P., C.I. Thornton, and S.R. AbT. 1996. Riparian stubble height and recovery of degraded streambanks. Rangelands 18:137-140.

Clary, W.P., and B.F. Webster. 1990. Riparian grazing guidelines for the Intermountain Region. Rangelands 12:209-212.

Daubenmire, R.F. 1959. A canopy-coverage method. Northwest Science 33:43-64.

Fox, J., And S. Weisberg. 2011. An R companion to applied regression. 2nd edition. Sage, Thousand Oaks, CA. http://socserv.socsci.mcmaster.ca/jfox/ Books/Companion

Goss, L.M. 2013. Understanding the relationship between livestock disturbance, the protocols used to measure that disturbance and stream conditions. Master's thesis, Utah State University, Logan, UT.

Heitke, J.D., E.K. Archer, J. Ryan, and B.B. Roper. 2011. Effectiveness monitoring for streams and riparian areas: sampling protocol for stream channel 
attributes. [Accessed 13 October 2017]. https:// www.fs.fed.us/biology/resources/pubs/feu/pibo/pibo -2011-EM_Stream_Sampling_Protocol.pdf

HeitKe, J.D., R.C. Heñderson, B.B. Roper, and E.K. ARCHER. 2008. Evaluating livestock grazing use with streambank alteration protocols; challenges and solutions. Rangeland Ecology and Management 61: $647-655$.

Hofmann, L., And R.E. Ries. 1991. Relationship of soil and plant characteristics to erosion and runoff on pasture and range. Journal of Soil and Water Conservation 46:143-147.

Hough-Snee, N., B.B. Roper, J.M. Wheaton, P. Budy, AND R.L. LOKTEFF. 2013. Riparian vegetation communities change rapidly following passive restoration at a northern Utah stream. Ecological Engineering 58:371-377.

Irvine, K.M., S.W. Miller, R.K. Al-ChOKhachy, E.K. ArCher, B.B. Roper, and J.L. Kershner 2015. Empirical evaluation of the conceptual model underpinning a regional aquatic long-term monitoring program using causal modelling. Ecological Indicators 50:8-23.

Kauffman, J.B., W.C. Krueger, and M. Vavra. 1983. Impacts of cattle on streambanks in northeastern Oregon. Journal of Range Management 36:683-685.

Kershner, J.L., E.K. Archer, M. Coles-Ritchie, E.R. Cowley, R.C. Henderson, K. Kratz, C.M. Quimby, D.L. Turner, L.C. Ulmer, AND M.R. Vinson. 2004a. Guide to effective monitoring of aquatic and riparian resources. General Technical Report RMRS-GTR121, U.S. Department of Agriculture, Forest Service, Rocky Mountain Research Station, Fort Collins, CO. $57 \mathrm{pp}$.

Kershner, J.L., B.B. Roper, N. Bouwes, R. Henderson, AND E. ARCHER. 2004b. An analysis of stream habitat conditions in reference and managed watersheds on some federal lands within the Columbia River basin. North American Journal of Fisheries Management 24:1363-1375.

Knapp, R.A., AND K.R. MatThews. 1996. Livestock grazing, golden trout, and streams in the Golden Trout Wilderness, California: impacts and management implications. North American Journal of Fisheries Management 16:805-820.

Knighton, D. 1998. Fluvial forms and processes. Oxford University Press, New York, NY.

Kozel, S.J., W.A. Hubert, and M.G. Parsons. 1989. Habitat features and trout abundance relative to gradient in some Wyoming streams. Northwest Science 63:175-182.

LAKE, P.S. 2000. Disturbance, patchiness, and diversity in streams. Journal of the North American Benthological Society 19:573-592.

Magilligan, F.J., AND P.F. MCDowell. 1997. Stream channel adjustments following elimination of cattle grazing. Journal of the American Water Resources Association 33:867-878.

Marlow, C.B., T.M. PogacniK, and S.D. Quinsey. 1987. Steambank stability and cattle grazing in southwestern Montana. Journal of Soil and Water Conservation 42:291-296.

Matthews, K.R. 1996. Diel movement and habitat use of California golden trout in the Golden Trout Wilderness. Transactions of the American Fisheries Society $125: 78-86$
McIntosh, B.A., J.R. Sedell, R.F. Thurow, S.E. Clarke, and G.L. Chandler. 2000. Historical changes in pool habitats in the Columbia River Basin. Ecological Applications 10:1478-1496.

McIver, J.D., AND M.L. MCInNIS. 2007. Cattle grazing effects on macroinvertebrates in an Oregon mountain stream. Society for Range Management 60: 293-303.

Meredith, C.M., B. Roper, And E. Archer. 2014. Reductions in instream wood in streams near roads in the interior Columbia River Basin. North American Journal of Fisheries Management 34:493-506.

Micheli, E.R., AND J.W. Kirchner. 2002. Effects of wet meadow riparian vegetation on streambank erosion. 2. Measurements of vegetated bank strength and consequences of failure mechanics. Earth Surface Processes and Landforms 27:687-697.

Myers, T.J., and S. Swanson. 1995. Impact of deferred rotation grazing on stream characteristics in central Nevada: a case study. North American Journal of Fisheries Management 15:428-439.

Myers, T.J., and S. Swanson. 1996. Long-term aquatic habitat restoration: Mahogany Creek, Nevada, as a case study. Journal of the American Water Resources Association 32:241-252.

Nimon, K., F. Oswald, and J.K. Roberts. 2013. yhat: interpreting regression effects. $\mathrm{R}$ package version 2.0-0. https://CRAN.R-project.org/package $=$ yhat

Nusslé, S., K.R. Matthews, and S.M. Carlson. 2017. Patterns and dynamics of vegetation recovery following grazing cessation in California golden trout habitat. Ecosphere 8(7):e01880. https://doi.org/10 $.1002 /$ ecs 2.1880

Pelster, A.J., S. Evans, W.C. Leininger, M.J. Trlica, AND W.P. ClaRY. 2004. Steer diets in a montane riparian community. Journal of Range Management 57:546-552

PlatTs, W.S. 1991. Livestock grazing. Pages 389-423 in W.R. Meehan, editor, Influences of forest and rangeland management on salmonid fishes and their habitats. American Fisheries Society Special Publication 19, Bethesda, MD.

PlatTS, W.S., AND R.L. NELSON. 1985. Stream habitat and fisheries response to livestock grazing and instream improvement structures, Big Creek, Utah. Journal of Soil and Water Conservation 40:374-379.

PRISM Climate Group, Oregon State University. 2012. Parameter-elevation regressions on independent slopes model climate mapping system data set. [Accessed 24 August 2012]. http://www.prism climate.org

Ranganath, S.C., W.C. Hession, and T.M. Wynn. 2009. Livestock exclusion influences on riparian vegetation, channel morphology, and benthic macroinvertebrate assemblages. Journal of Soil and Water Conservation 64:33-42.

R CORE TEAm. 2013. R: a language and environment for statistical computing. R Foundation for Statistical Computing, Vienna, Austria. http://www.R-project .org

Reeves, G.H., L.E. Benda, K.M. Burnett, P.A. Bisson, AND J.R. SEDELL. 1995. A disturbance-based ecosystem approach to maintaining and restoring freshwater habitats of evolutionary significant units of anadromous salmonids in the Pacific Northwest. Pages 334-349 in J. Nielsen, editor, Evolution and 
the aquatic ecosystem: defining unique units in population conservation. American Fisheries Society Symposium 17, Bethesda, MD.

Ripple, W.J., and R.L. Beschta. 2007. Restoring Yellowstone's aspen with wolves. Biological Conservation 138:514-519.

Roper, B.B., J.M. Buffington, S. Bennett, S.H. Lanigan, E. Archer, S.T. Downie, J. Faustini, T.W. Hillman, S. Hubler, K. Jones, et al. 2010. A comparison of the performance and compatibility of protocols used by seven monitoring groups to measure stream habitat in the Pacific Northwest. North American Journal of Fisheries Management 30: $565-587$.

Roper, B.B., B. Jarvis, and J.L. Kershner. 2007. The role of natural vegetative disturbance in determining stream reach characteristics in central Idaho and western Montana. Northwest Science 81:224-238.

Rosenfeld, J., M. Porter, and E. Parkinson. 2000. Habitat factors affecting the abundance and distribution of juvenile cutthroat trout (Oncorhynchus clarki) and coho salmon (Oncorhynchus kisutch). Canadian Journal of Fisheries and Aquatic Sciences $57: 766-774$.

SAUNDERS, W.C., AND K.D. FausCH. 2007. Improved grazing management increases terrestrial invertebrate inputs that feed trout in Wyoming rangeland streams. Transactions of the American Fisheries Society 136: 1216-1230.

SKINNER, Q.D. 1998. Stubble height and function of riparian communities. Pages 29-46 in Stubble height and utilization measurements: uses and misuses. Oregon Agriculture Experimental Station Bulletin 682, Corvallis, OR.

Stuber, R.J. 1985. Trout habitat, abundance, and fishing opportunities in fenced vs. unfenced riparian habitat along Sheep Creek, Colorado. Pages 310-314 in R.R. Johnson, C.D. Ziebell, D.R. Patton, P.F. Ffolliott, and R.H. Hamre, editors, Riparian ecosystems and their management: reconciling conflicting uses. General Technical Report RM-GTR-120, U.S. Department of Agriculture, Forest Service, Rocky
Mountain Forest and Range Experiment Station, Fort Collins, CO.

Swanson, S.R., S. Wyman, and C. Evans. 2015. Practical grazing management to meet riparian objectives. Journal of Rangeland Applications 2:1-28.

Trimble, S.W. 1994. Erosional effects of cattle on streambanks in Tennessee, USA. Earth Surface Processes and Landforms 19:451-464.

Trimble, S.W., and A.C. Mendel. 1995. The cow as a geomorphic agent-a critical review. Geomorphology 13:233-253.

Ungar, E.D., A. Genizi, and M.W. Demment. 1991. Bite dimensions and herbage intake by cattle grazing short hand-constructed swards. Agronomy Journal 83:973-978.

[USDI-BLM] United States Department of the Interior-Bureau of Land Management. 1999. Utilization studies and residual measurements. Interagency Technical Reference BLM/RS/ST-96/ $004+1730$, Bureau of Land Management, Denver, CO. 174 pp.

Veblen, K.E., D.A. Pyke, C.L. Aldridge, M.L. Casazza, T.J. Assal, and M.A. Farinha. 2014. Monitoring of livestock grazing effects on Bureau of Land Management land. Rangeland Ecology and Management 67:68-77.

Venables, W.N., AND B.D. Ripley. 2002. Modern applied statistics with S. 4th edition. Springer, New York, NY. ISBN 0-387-95457-0.

Whittingham, M.J., P.A. Stephens, R.B. Bradbury, and R.P. Freckleton. 2006. Why do we still use stepwise modeling in ecology and behavior? Journal of Animal Ecology 75:1182-1189.

WiNWARD, A.H. 2000. Monitoring the vegetation resources in riparian areas. General Technical Report RMRS47, U.S. Department of Agriculture, Forest Service, Rocky Mountain Research Station, Ogden, UT. 49 pp.

Received 23 August 2017

Revised 19 January 2018

Accepted 24 January 2018

Published online 30 April 2018 